\title{
Plant species as influenced by soil relations in a mangrove ecosystem of lower IMO river estuary, Niger Delta, Nigeria
}

\begin{abstract}
This study investigated the soil variables influencing plant species in a mangrove ecosystem of Lower Imo River Estuary, Niger Delta, Nigeria. A twenty (20) $10 \mathrm{~m} \times 10 \mathrm{~m}$ quadrat spaced at $25 \mathrm{~m}$ intervals along established transect was used in sampling the vegetation and soils. The quantified vegetation parameters were density, frequency, height, basal area and crown cover. Soil samples were obtained at two rooting depths $(0-15 \mathrm{~cm}$ and $15-30 \mathrm{~cm})$ and variables determined were $\mathrm{pH}$, electrical conductivity, exchange acidity, total nitrogen, organic carbon, available phosphorus, cations $(\mathrm{Ca}$, $\mathrm{Mg}, \mathrm{Na}$ and $\mathrm{K}$ ), ECEC, base saturation and particle sizes (sand, silt and clay). An aggregate of 11 species belonging to 9 families were found. The dominant species was Rhizophora mangle with density of $120.41 \pm 29.30 \mathrm{stems} / \mathrm{ha}$. Rhizophora mangle and Nypa fruticans were the most frequent species $(100 \%)$. Rhizophora mangle was the tallest $(11.50 \pm 1.52 \mathrm{~m})$ as well as the species with the widest crown cover $(10.68 \pm 1.06 \mathrm{~m} 2 / \mathrm{ha})$ while Elaeis guineensis had the largest basal area $(1.79 \pm 0.09$ m2/ha). Canonical Correspondence Analysis (CCA) showed that the abundance and distribution of plant species were swayed by the interplay of various soil factors in the mangrove. This delineated the first tier $(\mathrm{Na}, \mathrm{pH}, \mathrm{Mg}, \mathrm{K}$, base saturation, sand, silt, clay and ECEC) and the second tier (Ca, exchangeable acidity, total nitrogen, electrical conductivity and organic carbon) soil variables controlling plants' distributional patterns. Rhizophora mangle and Acrostichum aureum were influenced by $\mathrm{Na}$ while Nypa fruticans and Avicennia africana were influenced by $\mathrm{K}$ and $\mathrm{pH}$, respectively. On the other hand, Fimbristylis ferruginea, Uapaca staudtii and Paspalum vaginatum were influenced by $\mathrm{Mg}$, sand and clay correspondingly while M. ciliata, C. nucifera, E. guineensis and Dracaena arborea showed affinities to base saturation and ECEC. Hence, this study lends credence to species adaptation and diversity, habitat quality as well as providing baseline information on conservation and future management of this ecosystem.
\end{abstract}

Keywords: mangrove ecosystem, soil properties, plant distribution, lower IMO river estuary, canonical correspondence analysis
Volume 4 Issue 3 - 2019

\author{
Ita RE,' Ogbemudia FO,' Kekere O,' Udo \\ ED \\ 'Department of Botany and Ecological Studies, University of \\ Uyo, Nigeria \\ 2Department of Plant Science and Biotechnology,Adekunle \\ Ajasin University, Nigeria
}

Correspondence: Richard Ita, Department of Botany and Ecological Studies, University of Uyo, P. M. B. I017, Uyo, Akwa Ibom State, Nigeria, Tel +2348069290525,

Email alwaizfwesh247@yahoo.com

Received: March 19, 2019 | Published: May 03, 2019

\section{Introduction}

Mangrove is a rugged or complex terrain found along tropical coastal and tidal influenced environments. It is highly characterized by varying levels of salinity depending on its proximity to the ocean as well as the frequency of tidal flushing or inundations. Mangrove forests are beneficial both economically and ecologically to humans and to the society at large. They are sources of forestry and fishery derived products like charcoal, timber, honey, fishes, prawns, crabs and mollusks (Siddiqi, 1997), most species are used as medicines, ${ }^{1}$ they help in screening solar UV-B radiation, ${ }^{2}$ they mitigate greenhouse effects, ${ }^{3}$ control flooding ${ }^{4}$ and prevent coastal erosion. ${ }^{5}$ A mangrove dominated habitat may range from single to multi-species communities and these species are strongly influenced by several environmental variables such as salinity, soil type, temperature, freshwater supply as well as wave action. ${ }^{6,7}$ Of these factors, tidal flushing and exposure to varying salinity levels make the intertidal zone to be very complex and challenging for most plant species for their survival. However, for the survival of plants in this environment to be enhanced, mangrove species must be well adapted to both pedological and hydrological conditions. According to Ball, ${ }^{8}$ mangrove species possess quite distinct morphological, physiological, anatomical and reproductive features that promote their survival under high and variable salinity levels. The different levels of species adaptation to prevailing environmental factors at both spatial and temporal scales explain the structure or physiognomy of evidenced in many mangrove forests.

Since mangrove is quite dynamic in nature, several landforms which support the growth and proliferations of diverse species have emerged due to the dominating influences of environmental factors like tidal inundations, salinity, anoxia and temperature in this ecosystem. To this end, this study set out to investigate the primary environmental variables (soil) influencing plant community in this mangrove in order to understand the intricate relationships that exist between these components.

\section{Materials and methods}

\section{Study site}

This study was carried out in a mangrove ecosystem at Okorombokho in Eastern Obolo Local Government Area of Akwa Ibom State. Eastern Obolo Local Government is located in the Niger Delta fringe between Imo and Qua Iboe Rivers estuaries and lies between latitudes $4^{\circ} 28^{\prime}$ and $4^{\circ} 53^{\circ} \mathrm{N}$ and longitudes $7^{\circ} 50^{\circ}$ and $7^{\circ} 55^{\circ}$ E with an altitude of about $650 \mathrm{~m}$ above sea level (Figure 1). It is bounded in the North by Mkpat Enin Local Government Area, North 
East by Onna, West by Ikot Abasi, South East by Ibeno Local Government Areas and in the South by the Atlantic Ocean (Akwa Ibom State Government, AKSG, 2008). The climate of the area is that of humid tropic. Temperatures are usually high, ranging between $26^{\circ} \mathrm{C}$ and $28^{\circ} \mathrm{C}$. Rainfall is usually heavy with mean annual rainfall lying between $2,000-4,000 \mathrm{~mm}$. The area is characterized by two seasons; the rainy season and the dry season. Rainy season starts from April to November with high relative humidity and heavy cloud covers. The dry season begins in November and ends in March. Harmattan is experienced in December and January. The harsh hot tropical climatic conditions are moderated by the coastal location of the area.

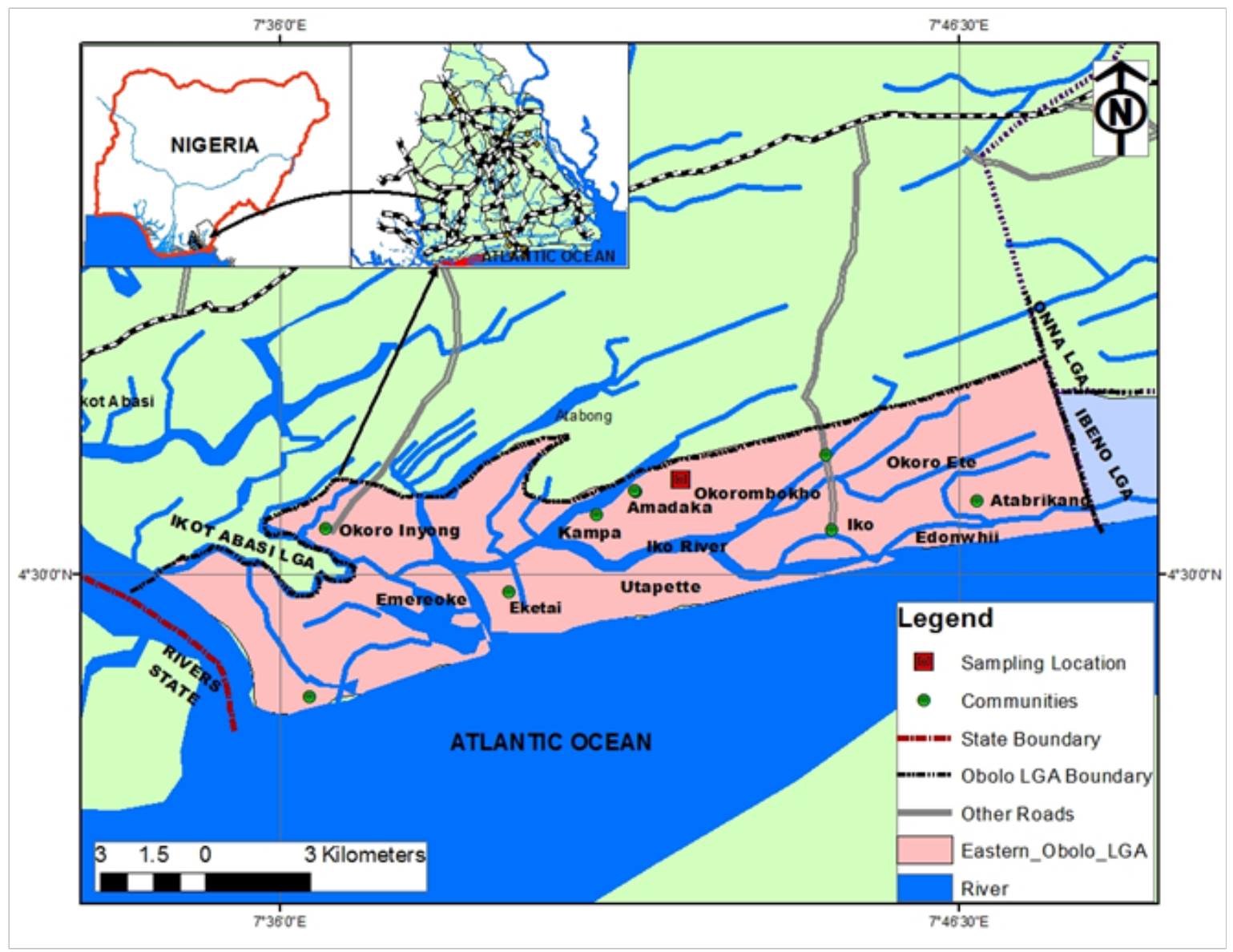

Figure I Map of the study area.

\section{Vegetation/soil sampling}

Vegetation and soil were sampled systematically using a twenty (20) $10 \mathrm{~m} \times 10 \mathrm{~m}$ quadrat set apart at $25 \mathrm{~m}$ intervals along established transect. In each quadrat, frequency, density, basal area, height and crown cover of species were measured. In each quadrat, soil samples were obtained at two rooting depths $(0-15 \mathrm{~cm}$ and $15-30 \mathrm{~cm})$ bulked and preserved in well labeled ziploc bags. The collected soil samples were then taken to the laboratory for their physical and chemical analyses.

\section{Determination of vegetation parameters}

Density: Density of plant species was determined using the method of Cochran. ${ }^{9}$

Frequency: The frequency of species was calculated using the formula below:

$$
\text { Frequency }=\frac{\text { Number of occupied quadrat for a species }}{\text { Total number of quadrats thrown }} \times 100
$$

Height: The height of woody species was measured using a Haga altimeter (43913 model). The reading was taken $15 \mathrm{~m}$ away from the base of the woody plant from where the crown was sighted through the eye piece of the altimeter and the upper reading taken. The base of the woody plant was similarly sited and the lower altimeter readings taken. The height of each species was calculated using the relation:

Height $(m)=$ Algebraic sum of the reading of the top and bottom of each plant $\times$ horizontal distance from observer to each species divided by scale factor used on the altimeter.

Basal Area: This was calculated using the formula:

$$
\text { Basal Area }=\frac{\mathrm{C}^{2}}{4 \pi}
$$

Where $4 \pi=4 \times 3.142=12.568$

$\mathrm{C}=$ girth size of the species at breast height 
Crown cover: The crown cover of woody plant species was determined by the crown cover diameter method as outlined by Muller- Dombios and Ellenberg. ${ }^{10}$

\section{Physical and chemical analysis of soil samples}

The $\mathrm{pH}$, electrical conductivity and exchange acidity were determined using Beckman's glass electrode $\mathrm{pH}$ meter, ${ }^{11}$ conductivity meter (Jenway Pcm 128723 model) and titration with $1 \mathrm{~N} \mathrm{KCL.}{ }^{12}$ Organic carbon, total nitrogen and available phosphorus were determined using the Walkey Black wet oxidation method, MicroKjeldahl method and Bray No 1 method. ${ }^{13} \mathrm{Ca}$ and $\mathrm{Mg}$ were determined using EDTA titration method while sodium and potassium were determined by photometry method. The Effective Cation Exchange Capacity (ECEC) was calculated by the summation method (that is summing up of the Exchangeable Bases and Exchange Acidity (EA). Base Saturation was calculated by dividing total Exchangeable Bases by ECEC multiplied by 100 . Sand, silt and clay were determined using Hydrometer method.

\section{Statistical data analyses}

This study hypothesized that the distribution of mangrove species is influenced by complex soil variables. In order to test this hypothesis, ordination technique through Canonical Correspondence Analyses (CCA) was used. Canonical ordination is a technique for relating the composition of plant communities directly to their environment. ${ }^{14}$ CCA ordination technique assumes a unimodal distribution of species in relation to environmental variables. ${ }^{15,16}$ Species cover abundance data for each plot together with the corresponding plot versus environmental variables data matrix were subjected to Canonical Correspondence Analysis (CCA) using PAST 3.0 to reveal the relations between the species composition and environmental variables.

\section{Results}

\section{Floristic inventory of the mangrove}

The floristic components of the mangrove showed a total of 11 species belonging to 9 families (Table 1). The family Arecaceae had the highest species representation (3) in the mangrove. Species density ranged between $13.41 \pm 4.00$ st/ha in Mytragyna ciliata and $120.41 \pm 29.30 \mathrm{st} / \mathrm{ha}$ in Rhizophora mangle. Nypa fruticans and Rhizophora mangle, respectively had the highest frequency of occurrence $(100 \%)$ while the species with the least frequency of occurrence of 20\% were Fimbristylis ferruginea, Mytragyna ciliata and Uapaca staudtii. Rhizophora mangle was the tallest species $(11.50 \pm 1.52 \mathrm{~m})$ as well as the species with the widest coverage $\left(10.68 \pm 1.82 \mathrm{~m}^{2} / \mathrm{ha}\right)$. Mytragyna ciliata was the shortest species $(3.08 \pm 0.31 \mathrm{~m})$ while Avicennia africana had the least crown cover $\left(0.48 \pm 0.005 \mathrm{~m}^{2} / \mathrm{ha}\right)$. Elaeis guineensis and Mytragyna ciliata had the largest $\left(1.79 \pm 0.09 \mathrm{~m}^{2} / \mathrm{ha}\right)$ and least basal area $\left(0.13 \pm 0.01 \mathrm{~m}^{2} / \mathrm{ha}\right)$ values, respectively. Most species were ephemerals with negligible girth sizes and coverage.

\section{Physical and chemical properties of the mangrove soil}

The physical and chemical properties of the soil are presented spatially in Table 2. The $\mathrm{pH}$ of the soil ranged from 7.10 in station 1 to 7.30 in station 2. Electrical conductivity ranged from 10.30 to $15.12 \mathrm{ds} / \mathrm{m}$ with the highest and least values in stations 3 and 1 . Organic carbon $(7.30 \pm 0.25 \%)$, available phosphorus $(8.36 \pm 0.07 \mathrm{mg} /$ $\mathrm{kg})$, magnesium $(4.76 \pm 0.08 \mathrm{cmol} / \mathrm{kg})$ sodium $(3.47 \pm 0.001 \mathrm{cmol} / \mathrm{kg})$ and sand $(66.46 \pm 3.10 \%)$ had the highest values in station 3 while station 2 recorded the highest values for total nitrogen $(0.21 \pm 0.03$ $\%)$, calcium $(10.20 \pm 0.45 \mathrm{cmol} / \mathrm{kg})$, potassium $(1.76 \pm 0.01 \mathrm{cmol} / \mathrm{kg})$, ECEC $(20.42 \pm 0.78 \mathrm{cmol} / \mathrm{kg})$, base saturation $(84.82 \pm 3.00 \%)$ and clay $(33.24 \pm 0.86 \%)$. Station 1 had high values for exchangeable acidity $(3.22 \pm 0.05)$ and silt $(16.30 \pm 0.87 \%)$.

Table I Floristic inventory of the mangrove

\begin{tabular}{|c|c|c|c|c|c|c|}
\hline Plant Species & Family & $\begin{array}{l}\text { Frequency } \\
\text { (\%) }\end{array}$ & $\begin{array}{l}\text { Density (St/ } \\
\text { ha) }\end{array}$ & Height (m) & Basal area $\mathrm{m}^{2} / \mathrm{ha}$ & Crown Cover $\mathrm{m}^{2} / \mathrm{ha}$ \\
\hline Acrosticum aureum L. & Pteridaceae & 60 & $55.00 \pm 8.60$ & $4.12 \pm 0.98$ & - & - \\
\hline Avicennia africana P. Beau & Avicenniaceae & 80 & $45.00 \pm 7.50$ & $5.02 \pm 0.95$ & $0.18 \pm 0.04$ & $0.48 \pm 0.005$ \\
\hline Cocus nucifera $\mathrm{L}$. & Arecaceae & 60 & $17.00 \pm 4.53$ & $6.58 \pm 0.23$ & $|.3| \pm 0.08$ & $6.09 \pm 1.08$ \\
\hline Elaeis guineensis Jacq. & Arecaceae & 60 & $30.00 \pm 5.11$ & $8.50 \pm 0.85$ & $1.79 \pm 0.09$ & $9.72 \pm 1.06$ \\
\hline Fimbristylis ferruginea (L) Vahl & Cyperaceae & 20 & $32.10 \pm 5.67$ & - & - & - \\
\hline $\begin{array}{l}\text { Mytragyna ciliata (Aubrev and } \\
\text { Pellegr) }\end{array}$ & Rubiaceae & 20 & $|3.4| \pm 4.00$ & $3.08 \pm 0.31$ & $0.13 \pm 0.01$ & $2.10 \pm 0.68$ \\
\hline Nypa fruticans Wurmb. & Arecaceae & 100 & $109.32 \pm 22.01$ & $4.4 I \pm 0.39$ & $0.2 I \pm 0.00$ & $4.23 \pm 0.81$ \\
\hline Paspalum vaginatum $\mathrm{Sw}$. & Poaceae & 40 & $40.12 \pm 7.21$ & - & - & - \\
\hline Rhizophora mangle L. & Rhizophoraceae & 100 & $|20.4| \pm 29.30$ & $11.50 \pm 1.52$ & $0.92 \pm 0.05$ & $10.68 \pm 1.82$ \\
\hline Uapaca staudtii Pax & Euphorbiaceae & 20 & $15.36 \pm 4.03$ & $7.20 \pm 1.00$ & $0.80 \pm 0.04$ & $3.24 \pm 0.67$ \\
\hline $\begin{array}{l}\text { Dracaena arborea (Willd) } \\
\text { Link }\end{array}$ & Liliaceae & 40 & $25.00 \pm 4.91$ & $6.12 \pm 0.98$ & $0.5 \mathrm{I} \pm 0.03$ & $1.10 \pm 0.42$ \\
\hline
\end{tabular}

\pm Standard error 
Table 2 Physical and Chemical Properties of the Soil

\begin{tabular}{llll}
\hline Parameters & Station I & Station 2 & Station 3 \\
\hline $\mathrm{PH}$ & $7.10 \pm 1.10$ & $7.30 \pm 1.15$ & $7.21 \pm 1.04$ \\
$\mathrm{Ec}(\mathrm{ds} / \mathrm{m})$ & $10.30 \pm 2.30$ & $12.34 \pm 2.00$ & $15.12 \pm 2.86$ \\
Organic carbon (\%) & $6.30 \pm 0.14$ & $7.14 \pm 0.21$ & $7.30 \pm 0.25$ \\
Total nitrogen (\%) & $0.16 \pm 0.04$ & $0.21 \pm 0.03$ & $0.19 \pm 0.03$ \\
Available Phosphorus (mg/kg) & $5.12 \pm 0.03$ & $6.41 \pm 0.05$ & $8.36 \pm 0.07$ \\
Calcium (cmol/kg) & $8.00 \pm 0.25$ & $10.20 \pm 0.45$ & $9.40 \pm 0.35$ \\
Magnesium (cmol/kg) & $4.00 \pm 0.05$ & $4.68 \pm 0.06$ & $4.76 \pm 0.08$ \\
Sodium (cmol/kg) & $1.93 \pm 0.003$ & $2.68 \pm 0.005$ & $3.47 \pm 0.02$ \\
Potassium (cmol/kg) & $1.40 \pm 0.00$ & $1.76 \pm 0.01$ & $0.45 \pm 0.01$ \\
Exchange acidity & $3.22 \pm 0.05$ & $3.10 \pm 0.04$ & $2.80 \pm 0.01$ \\
ECEC (cmol/kg) & $17.55 \pm 1.45$ & $20.42 \pm 0.78$ & $17.88 \pm 1.75$ \\
Base saturation (\%) & $81.65 \pm 2.14$ & $84.82 \pm 3.00$ & $84.34 \pm 3.05$ \\
Sand (\%) & $60.36 \pm 2.63$ & $60.46 \pm 2.50$ & $66.46 \pm 3.10$ \\
Silt (\%) & $16.30 \pm 0.87$ & $6.30 \pm 0.41$ & $11.30 \pm 0.67$ \\
Clay (\%) & $23.34 \pm 0.95$ & $33.24 \pm 0.86$ & $22.24 \pm 0.92$ \\
\hline
\end{tabular}

\pm SE; Standard Error

\section{Canonical correspondence analysis}

The CCA ordination of plant communities in relation to nutrient gradient is presented in Figure 2 while the eigen values and percentage variances of the principal axis is presented in Table 3. This was performed using the numerical scores of species (density) across the sampled plots. From the result, CCA ordination of the first three (3) out of ten (10) canonical axes accounted for $100 \%$ of the total variance in the data set. These axes bear vital information regarding the variations in plant distribution along environmental gradients. The cumulative percentage of the first two axes explained $96.77 \%$ of the total variance while the third axis accounted for the remaining 3.23 $\%$ (Table 3). In the triplot, (Figure 2), small thick circles represent the plant species communities while the arrow lines represent the soil variables (vectors) for which the species had affinity for. The length of the arrows is proportional to the magnitude or intensity of change owing to environmental variables while the direction of the arrow shows their correlation with the axes. Longer arrows reflect stronger effects on plant community establishment and vice versa. Also, the distance of a named species from the vector lines connotes its preference or affinity to the vector.

Table 3 Eigenvalues, species-environment correlation coefficients, and cumulative percentage for the first three axes

\begin{tabular}{llll}
\hline Axis & Eigenvalue & \% variance explained & Cumulative variance \\
\hline 1 & 0.14382 & 68.45 & 68.45 \\
2 & 0.059497 & 28.32 & 96.77 \\
3 & 0.006803 & 3.23 & 100 \\
\hline
\end{tabular}

From the triplot, the relationships between the plant communities, their site preferences and soil nutrient gradient were established (Figure 1). The primary and most influential soil attributes on species distribution in the mangal were; $\mathrm{Na}$, base saturation, $\mathrm{pH}$, silt, clay, $\mathrm{K}, \mathrm{Mg}$, available phosphorus and sand. R. mangle and A. aureum exhibited high affinity for $\mathrm{Na}, A$. africana and $N$. fruticans showed higher preferences for $\mathrm{pH}$ and $\mathrm{K}$ while the distribution of $F$. ferruginea was greatly influenced by available phosphorus. U. staudtii showed higher affinity for sandy substrates, Elaeis guineensis, Mytragyna ciliata, Dracaena arborea and C. nucifera showed higher affinity for base saturation while the distribution of $P$. vaginatum was influenced by clay substrates. Other soil variables such as organic carbon and electrical conductivity had intermediary influences on distribution of plant communities. 


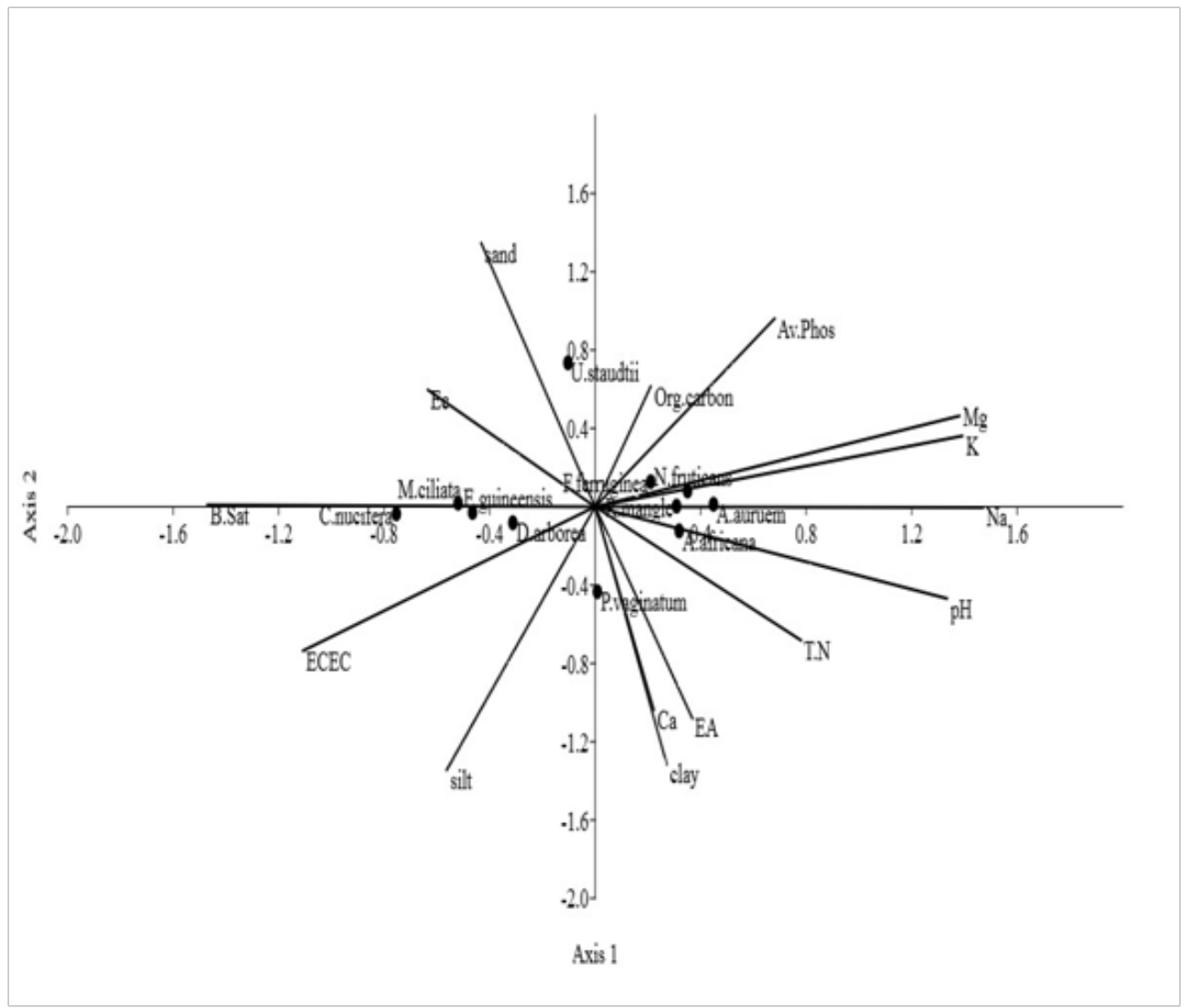

Figure 2 Canonical Correspondence Analysis (CCA) for soil-species variables.

Abbreviations for vegetation components are as follows: P.vaginatum (Paspalum vaginatum), A.africana (Avicennia africana), R.mangle (Rhizophora mangle), A.aureum (Acrostichum aureum), N.fruticans (Nypa fruticans), F.ferruginea (Fimbrystylis ferruginea), U.staudtii (Uapaca staudtii), M.ciliata (Mytragyna ciliata). E.guineensis (Elaeis guineensis), C.nucifera (Cocus nucifera), D.arborea (Dracaena arborea) Abbreviations for environmental variables are as follows: B. Sat (Base Saturation), ECEC (Effective Cation exchange Capacity), EA(Exchangeable Acidity), $\mathrm{Ca}$ (Calcium), T.N (Total Nitrogen), Na (Sodium), K (Potassium), Mg (Magnesium), Av.Phos. (Available Phosphorus), Org. carbon (Organic Carbon), Ec (Electrical Conductivity).

\section{Discussion}

The floristic catalogue of this mangrove showed relatively low species diversity when compared to the values reported by other scholars in various mangrove ecosystems. For instance, Ukpong, ${ }^{17}$ reported 34 species in Creek Town mangrove swamp, Nigeria. The distribution of plants in the mangal varied among species owing to their responses to complex environmental (soil) conditions. This highlights that the soil variables exerted greater influences on the distributional patterns of the flora in the mangal. While species such as $R$. mangle and $N$. fruticans were widely distributed with higher frequencies of occurrence and numerical scores (density), others most especially the mangrove associes were narrowly distributed or restricted to certain sites. This may reflect an overlap in environmental and soil conditions or overlapping tolerance of stress factors such as salinity variations and tidal flushing. ${ }^{17}$ On the whole, true mangrove species such as $N$. fruticans, $R$. mangle, A. africana and A. aureum had higher densities and frequencies when compared to the associate species. This is not unrelated to the fact that the former had better adaptation to saline conditions than the latter. Despite this, the occurrence of the associate species in this mangrove which are basically found in fresh water zones may entail their adaptation to brackish habitats. The dominance of Rhizophora mangle in this mangrove aligns with the findings of Strauch et al. ${ }^{18}$ and Zamprogno et al. ${ }^{19}$ while working in mangroves of Bahamas Island and mangrove forest in southeastern Brazil. Elsewhere, Savory ${ }^{20}$ and Abere \& Ekeke ${ }^{21}$ had reported Rhizophora racemosa to be the pioneer mangrove species on the shorelines of Nigeria. This however contrasts with the findings of this study and may accentuate the transition and succession going on in many Nigerian mangroves over time. The effective reproductive strategies of $R$. mangle and $N$. fruticans may further explain their massive proliferations in this mangrove. The former exhibits vivipary (the condition where mangrove embryo germinates while still attached to the parent plant) while the latter exhibit hydrochory (the means by which mangrove seeds, fruits or propagules are dispersed by water). Vivipary increases the chances of successful establishment in an unpredictable environment where germination of seeds would typically be inhibited. ${ }^{22}$ This may further justify the dominance of $R$. mangle in terms of density. In addition, the infiltrations of $N$. fruticans in various plots may signify several anthropogenic perturbations in the ecosystem. Ukpong ${ }^{23}$ opined that $N$. fruticans is a manifestation and a secondary successor to any destroyed or degraded mangrove stand. 
Secondary succession abounds when the true mangrove species have been destroyed by human activity like harvesting of timber species for construction or fuel wood. This makes the saplings on reaching a substrate that is rid of vegetation to be more vigorous in growth than most mangrove propagules and eventually dominate and overtake the former mangrove habitat.

The $\mathrm{pH}$ of the soil, the high $\mathrm{Na}$ content as well as the high electrical conductivity are not unprecedented but rather typify mangrove ecosystems and convey a salic character to the soil. This may have arose on the basis of frequent flooding and tidal flushing with saline waters from the ocean into the area. ${ }^{24}$ Nutrients such as organic carbon and nitrogen were relatively low. This is may be attributed to low litter decomposition and mineralization rates. The high sand contents in the soil might have also contributed to the low retention of these nutrients due to its high porosity and drainage. According to Li et al. ${ }^{25}$ and Reef et al., ${ }^{26}$ many mangrove sediments are typically low in nutrients where the flooded soils greatly restrain nitrification and the microbial formation of $\mathrm{NO}^{3--}$ This results in a low nutrient bioavailability in the intertidal sediments. The values obtained for ECEC spatially showed that the soil had a good sink for cations. The textural class showed a sandy clay loam soil with a high percentage of sandy particles recorded over silt and clay. This is in consonance with the findings of Moreno \& Calderon ${ }^{27}$ and Ferreira et al..$^{28}$

The use of Canonical Correspondence Analysis (CCA) in this study discerned patterns in the species composition relating to the measured environmental variables (Ter Braak, 1987, 1988). The distribution of the species in the mangrove was greatly influenced by $\mathrm{Na}$ (salinity), base saturation, textural class (sand, clay and silt), ECEC, $\mathrm{pH}, \mathrm{Mg}$ and $\mathrm{K}$. The affinities of $R$. mangle, A. aureum, $N$. fructicans, $N$. fruticans, and $A$. africana to sites influenced by salinity ( $\mathrm{Na}$ and $\mathrm{pH}>7$ ) accentuate a soil salinity gradient thereby justifying them as core halophyte species. In addition, their affinities to $\mathrm{Na}$ and $\mathrm{pH}$ may highlight their abilities to thrive and adapt under saline environments. Soil $\mathrm{pH}$ according to Dong et al. ${ }^{29}$ is an important determinant of the productivity of a site and in the segregation of plant groups. This view goes a long way to confirm the spatial segregation and niche preference of species where the true mangrove species thrived better under saline conditions with higher densities and frequency values than the mangrove associates or associes. These mangrove associates were predominant in niches less influenced by salinity and tidal inundations. The segregation and bonding of the mangrove associates (M. ciliata, C. nucifera, E. guineensis and D. arborea to base saturation and ECEC may confirm the views of Verma \& Verma ${ }^{30}$ that they act as nutrient reserves where plants utilize soil nutrients majorly cations for their growth and productivity. The intrinsic role the textural class in plant species distribution cannot be overlooked and underestimated. According to Ubom, ${ }^{31}$ silt and clay particles enhance the growth of species by improving soil water holding capacity, nutrient retention, cation exchange capacity, porosity and play a cementing role between mineral particles. Sand particles on the other hand, help in loosening mud soils by allowing permeability of water and root penetration by plants because of its large structural pores. This justifies the affinity of a $U$. staudtii and $P$. vaginatum to sandy and clayey substrates, respectively. The bonding of $N$. fruticans to potassium influenced niches underlines the importance and involvement of potassium in various physiological processes in plants such as improving enzyme activation, photosynthesis, assimilates, water relations, transportation, as well as plant growth and development. ${ }^{32}$ If the supply of K to plant is low or poor, synthesis of protein will be stalled making the forerunners of protein (amides, amino acids and nitrates) to accumulate. ${ }^{33} \mathrm{~F}$. ferruginea showed an affiliation with magnesium in the mangal and its function in plant species distribution is very pivotal. Magnesium, being a central atom of chlorophyll plays an important role in photosynthesis and healthy growth of plants when supplied in sufficient quantity. ${ }^{34}$ Hence, its insufficiency vitiates the chlorophyll content resulting in chlorosis.

\section{Conclusion}

This study highlighted the variations in species abundance due to adaptability to environmental conditions as well the interrelationships between the soil and vegetation components. It also revealed that the soil variables exerted greater influences on the distributional patterns of the species in the ecosystem. The affinities of the species and adaptation to soil factors were visible using Canonical Correspondence Analysis (CCA). This revealed the net ranking of soil variables influencing the vegetation components into the first tier $(\mathrm{Na}$, $\mathrm{pH}, \mathrm{Mg}, \mathrm{K}$, base saturation, sand, silt, clay and ECEC) and the second tier $(\mathrm{Ca}$, exchangeable acidity, total nitrogen, electrical conductivity and organic carbon) soil variables.

Conclusively, vegetation and soil are the most conspicuous resources of wetlands and understanding the current vegetation and the distribution patterns of species assemblage can enhance the succession of vegetation restoration. In order to effectively understand wetland ecosystems, vegetation communities must be incorporated in view of all of the interrelated biotic and abiotic influences. This will aid stakeholder's particularly environmental agencies and conservationists in understanding the soil-species relationships while also assisting in the management, reclamation and protection of wetland ecosystems.

\section{Acknowledgments}

None.

\section{Conflicts of interest}

The authors declared there is no conflict of interest.

\section{References}

1. Kathiresan K. A review of studies on Pichavaram mangrove, southeast India. Hydrobiologia. 2000;430:185-205.

2. Moorthy P, Kathiresan K. Influence of UV-B radiation on photosynthetic and biochemical characteristics of a mangrove Rhizophora apiculata Blume. Photosynthetica. 1997;34(3):465-471.

3. Kathiresan K, Bingham BL. Biology of mangroves and mangrove ecosystems. Advances in Marine Biology. 2001;40:81-251.

4. Ridd PV, Sam R. Profiling groundwater salt concentrations in mangrove swamps and tropical salt flats. Estuarine, Coastal and Shelf Science. 1996;43(5):627-635.

5. Harada K, Imamura F, Hiraishi T. Experimental study on the effect in reducing Tsunami by the coastal permeable structures. USA: Final Proc Int Offshore Polar Eng Conf; 2002:652-658.

6. Cintron G, Novelli YS. Methods for studying mangrove structure, In: Snedaker SC, Snedaker JG, editors. The mangrove ecosystem: research methods. Paris: United Nations Educational, Scientific and Cultural Organization; 1984:91-113. ISBN 978-9231021817.

7. Connolly RM, Lee SY. Mangroves and Saltmarsh. In: Connell SD, Gillanders BM, editors. Marine Ecology, New York: Oxford University Press; 2007:485-514. 
8. Ball MC. Salinity tolerance in the mangroves Aegiceras corniculatum and Avicennia marina I. Water use in relation to growth, carbon partitioning, and salt balance. Australian Journal of Plant Physiology. 1988;15:447464.

9. Cochran WG. Sampling techniques. 2nd ed. New Delhi: Wiley Eastern Limited; 1963. 413 p.

10. Muller-Dombois D, Ellenberg H. Aims and Methods of Vegetation Ecology. London: John Wiley; 1974. 98 p.

11. McClean T. Soil science made easy. Washington DC: Vinyl Press; 1961:169-223.

12. Kramprath EJ. Conservation of soils and Tissue Testing for accessing the phosphorus status of soils. In: Khagwnch, editor. The Role of phosphorus in Agriculture, American Society of Agronomy. 1967;5:433-469.

13. Jackson MI. Soil Chemical Analysis. Prentice-Hall Inc, New Jersey: Englewood Cliffs; 1962.498 p.

14. Ter Braak CJF. Canonical correspondence analysis: a new eigenvector technique for multivariate direct gradient analysis. Ecology. 1986;67(5):1167-1179.

15. McCune B, Grace JB. Analysis of ecological communities. MjM Software Design, Oregon: Gleneden Beach; 2002.

16. McCune B, Mefford MJ. Multivariate analysis of ecological data: version 3.09. MjM Software, Oregon, USA: Gleneden Beach; 1997.

17. Ukpong IE. Mangrove swamp at a saline/fresh water interface near Creek Town, Southeastern Nigeria. Catena. 1997;29(1):61-71.

18. Strauch AM, Cohen S, Ellmore GS. Environmental influences on the distribution of mangroves on Bahamas Island. Journal of Wetlands Ecology. 2012;6:16-24.

19. Zamprogno GC, Tognella MMP, Quaresma V, et al. The structural heterogeneity of an urbanized mangrove forest area in southeastern Brazil: Influence of environmental factors and anthropogenic stressors. Brazilian Journal of Oceanography. 2016;64(2):157-172.

20. Savory HJ. A note on the ecology of Rhizophora in Nigeria. Kew Bell. $1953 ; 1: 127-128$

21. Abere SA, Ekeke BA. The Nigerian Mangrove and Wildlife Development Mediterranean Journal of Social Sciences. 2011;2(7):107-116.
22. Tomlinson PB. The Botany of Mangroves. Cambridge, UK: Cambridge University Press; 1986. 210 p

23. Ukpong IE. The Nypa fruticans threat in estuaries east of the Niger Delta, Nigeria. Trans Nig Soc Biol Conserv. The Status of Conservation Renewable Natural Resources in the Niger Delta Area of Nigeria. 2002:55-65.

24. Embrapa E. Brazilian Agricultural Research Corporation. Brazilian Soil Classification System. Rio de Janeiro. 2009.

25. Li YL, Fan XR, Shen QR. The relationship between rhizosphere nitrification and nitrogen-use efficiency in rice plants. Plant Cell Environ. 2008;31(1):73-85.

26. Reef R, Feller IC, Lovelock CE. Nutrition of mangroves. Tree Physiology. 2010;30:1148-1160.

27. Moreno ANM, Calderon JHM. Quantification of organic matter and physical-chemical characterization of mangrove soil at Hooker Bay, San Andres Island-Colombia. Lisbon, Portugal: Proceedings of the Global Conference on Global Warming; 2011:1-7.

28. Ferreira TO, Otero XL, de Souza Jr VS. et al. Spatial patterns of soil attributes and components in a mangrove system in Southeast Brazil (Sao Paulo). Journal of Soils Sediments. 2010;10:995-1006.

29. Dong L, Xu LG, Xu JX, et al. Effects of Soil Environmental Factors on Vegetation Distribution in Shoaly Wetlands Typical to Poyang Lake. Acta PedologicaSinica. 2014;51(3):618-626.

30. Verma SK, Verma M. A textbook of plant physiology, biochemistry and biotechnology. 6th ed. New Delhi: S. Chand and Company Ltd; 2007:9395

31. Ubom RM. Soil properties influencing the abundance and distribution of isoberlinia woodlands in Nigeria. International Journal of Soil Science. 2006;1(3):207-217.

32. Zlatev Z, Lidon FC. An overview on drought induced changes in plant growth, water relations and photosynthesis. Emirates Journal of Food and Agriculture. 2012;24(1):12-21.

33. Helal HM, Mengel K. Nitrogen metabolism of young barley plants as affected by $\mathrm{NaCl}$ salinity and potassium. Plant Soil. 1979;51:457-462.

34. Hermans C, Vuylsteke M, Coppens F, et al. Systems analysis of the responses to long-term magnesium deficiency and restoration in Arabidopsis thaliana. New Phytologist. 2010;187(1):132-144. 